\title{
EMPLOYMENT OF CORPORATE EXECUTIVES BY MAJORITY STOCRHOLDERS
}

BY JOHN F. MECK, JR. †

"THE BUSINESS of a corporation shall be managed by its board of directors." 1 In this simple, abrupt statement is embodied a rule of law which is part of the corporation statutes of almost every state. 2 Though innocuous on its face, this rule has been applied by the courts with telling effect to invalidate a particular type of contract, and much chagrin has been caused to the unsuspecting lawyers who drew such contracts.

The contract involved is one between the majority stockholder and one of the minority stockholders of a corporation in which the large proportion of the stock is owned by a single individual or by another corporation. ${ }^{3}$ The contract ordinarily imposes upon the majority stockholder at least two personal obligations: first, that the minority stockholder shall be a director of the corporation; and second and more important, that he shall hold a certain executive position in the corporate management at a specified compensation, for a period of time which may be a definite number of years or for as long as he holds his minority stock interest, or in some instances for his lifetime. These two integral obligations are well illustrated by the contract in the case of Clark :". Dodge, which obligated the majority stockholder to vote his stock and to vote as a director so that the minority stockholder should: (1) continue as a director of the corporation; (2) continue as its general manager -so long as he was "faithful, efficient and competent"; and (3) receive one-fourth of the net income of the corporation either by way of salary or dividends. While no period of time was specified for the duration of the contract, it was implicit that it should last for the lifetime of the contracting minority stockholder."

†Assistant Professor of Law, Yale Law School.

1. N. Y. GEN. CORP. LAW \$27.

2. Thirty-eight states have statutory provisions similar to that of New York, sixteen being almost identical with it. There is little doubt but that the rule is implicit in the corporation laws of the remaining states.

3. A rough estimate, based on some thirty cases involving contracts of the type here under consideration, discloses that in over half there was a single majority stoclholder. Of the remainder many were cases where two stockholders, teezuse of family or other ties, may be considered for all practical purposes as a single majority stoclsholder. The instances where a large number of stockholders combined to form a majority interest and then entered into a contract of this type are relatively few.

4. 269 N. Y. 410,199 N. E. 641 (1936). A further provision prohibited the payment of "unreasonable or incommensurate salaries" to other officers which would have the effect of reducing the net income of the corporation and thereby substantially affect the minority stockholder's one-fourth interest therein. 
For over fifty years courts have been prone to hold invalid the second obligation contained in this type of contract on the ground that it violated the rule that the business of a corporation shall be managed by its board of directors. ${ }^{5}$ The agreement, of course, falls within the category of contracts for executive employment which ordinarily are not enforcible by a decree of specific performance. ${ }^{6}$ But notwithstanding the fact that an employee usually may recover damages for a breach of an employment contract by his employer, courts deny even this remedy for repudiation of the bargain by the majority stockholder. Despite such judicial disapproval, attempts constantly are being made to use such agreements. While no single explanation is adequate, the reason probably lies in the fact that such contracts afford a practical solution for certain problems of corporate management, particularly in the case of those corporations with only a few stockholders, which are little more than chartered partnerships. ${ }^{7}$ In most of the cases one or both of two similar factual situations will be found. A corporation may desire to expand through the absorption of a smaller enterprise. The owner of the latter, having no inclination to retire from business, will consent to the combination only upon being assured an executive position in the management of the combined enterprises. ${ }^{8}$ Or a corporation may have reached a point where the services of an experienced executive are essential to the successful operation of the business. To get an individual of the requisite ability, or in some instances to retain such a person in the corporation's employ, a status above that of a mere employee must be offered. ${ }^{\circ}$ In either situation a process of bargaining takes place, resulting ordinarily in an understanding that the particular individual shall become a stockholder and director of the corporation, and that he shall occupy an executive position giving him a measure of control over the corporate affairs.

Often, however, the prospective executive will want more than a mere understanding that all this will take place. He may desire some legal remedy which will enable him to insist that the terms of the agreement be carried out or which will afford him some means of redress in the event

5. Confined to the cases in which the issue of the validity of such contracts was presented squarely, a rough calculation would be that in over two-thirds the courts invalidated the contracts.

6. But cf. Clark v. Dodge, 269 N. Y. 410,199 N. E. 641 (1936) ; Jones v. Williams, 139 Mo. 1,39 S. W. 486,40 S. W. 353 (1897) (injunction).

7. There is no reason why this type of contract cannot be used in the case of large corporations, and isolated instances of such use can be found.

8. E.g., West v. Camden, 135 U. S. 507 (1890) ; Thielsen v. Blake, Moffitt \& Towne, 142 Ore. 59, 17 P. (2d) 560 (1932); cf. Mansfield v. Lang, 200 N. E. 110 (Mass. 1936). When used in this way the contract often will be found to be part of a general preorganization agreement by which a new corporate entity is to be i.jrmed.

9. E.g., Clark v. Dodge, 269 N. Y. 410,199 N. E. 641 (1936): Hayden v. Beane, 199 N. E. 755 (Mass. 1936); Timme v. Kopmejer, 162 Wis. 571, 156 N. W. 961 (1916). 
they are rot. A method which at once suggests itself is a contract with the corporation obligating it to carry out the various provisions of the understanding. Such contracts are quite common, but there are several reasons why they are unsatisfactory and why the incoming executive will attempt to secure a contract with the majority stockholder. Negotiations usually will be conducted personally with the dominant stockholder, for an individual seeking effective legal protection naturally will disregard the fiction of the corporate entity and seek to bind directly the ultimate power in the corporate affairs. ${ }^{10}$ If at any time the ouster of such an individual is contemplated, a majority stockholder who may be held personally responsible is less likely to disregard the consequences than he would be if only the corporation were liable. Furthermore, serious doubts may exist as to the validity of a contract binding a corporation to keep an individual in a specified office, especially in regard to the term for which the office is to be held. In some instances these doubts arise from statutory provisions; ${ }^{11}$ in others from a feeling on the part of the cousts that such contracts improperly restrict the judgment of future boards of directors. ${ }^{12}$ Finally, since the directors are elected by the

10. E.g., Jones v. Williams, 139 Mo. 1,39 S. W. 486,40 S. W. 353 (1897). There the majority stockholder was the famous newspaper owner, Joseph Pulitzer, and the corporation published the St. Louis Post-Dispatch. Pulitzer's domination of the management of the newspaper which his corporations controlled was common knowledge, and no one would have thought of dealing in any way except directly with Pulizer. While the court interpreted the contract as having been made by Pulitzer on behalf of the corporation, the decision is still applicable to the problem here under consideration. For the background of this case, see Sertz, Joseph Ptutzer, His Life \& Letters (1924) 191 et seq.

11. For example the National Banking Act provides that the board of directors may remove officers "at will." REv. STAT. $\$ 5136$ (1875), 12 U. S. C. $\$ 24$ (1934). The New York statutes provide that the directors may remove officers "at pleasure" $N$. Y. Stoes Corp. LAw $\$ 60$. West Virginia and Washington formerly had similar provisions which have since been repealed. Under the National Banking Act the courts uniformly held that officers employed under contracts for a term of years nonetheless could be removed without liability to the corporation. The New York courts have never squarely passed on the point, but in the federal court the New: York statute has been interpreted as not relieving the corporation from liability. In re Paramount Publix Corp., 90 F. (2d) 441 (C. C. A. 2d, 1937). See generally, Comment (1937) 50 HARv. L. Rev: 518.

It is interesting to note that several states have recently enacted a provision clearing up this diffeulty. It permits the board of directors to remove any officer whenever it is deemed in the best interests of the corporation to do so, but expressiy provides that such removal is without prejudice to the contract rights of the person so removed. See Insro Code AnN. (1932) § 29-140; Ill Rev. Stat. (1937) c. 32, \$157.43; LA. Gen. Stax. A.3:3. (Dart, 1932) § 1115; PA. Stat. ANn. (Purdon, Supp. 1938) tit. 15. \$2852-407; Wasm. Rev. Stat. ANv. (Remington, 1932) \$3803-31. This type of provision is also in the Uniform Business Corporation Act, $\$ 32$.

12. This feeling is particularly strong in cases whiere the employment contracts purport to be perpetual or for the lifetime of the employee. Carney v. New York: Life Insurance Co., 162 N. Y. 453,57 N. E. 78 (1900); Borland v. John F. Sass Printing Co., 95 Colo. 53, 32 P. (2d) 827 (1934) ; Beaton v. Continental Southland Sav. \& Loan Ass'n, 
stockholders, it is apparent that the corporation itself lacks power to make anyone a director. For these reasons the prospective executive will seek as many other safeguards as his bargaining position will permit. If it is sufficiently strong he may force negotiations to the point where the majority stockholder agrees personally to guarantee his right to participate in the management of the corporate affairs. A further possibility is that the ultimate "deal" may give him two strings to his bow through a contract binding both the corporation and the majority stockholder. That such a double guarantee may be highly desirable will appear later.

Before turning to specific reasons for the frequent invalidation of these contracts it is worth while first to look at the underlying legal theory with respect to the management of the business of a corporation and to contrast that theory with the practical situation of a corporation with a single majority stockholder. There will be found in every corporation three groups of persons; the stockholders, the directors, and the executive officers. Often these groups will overlap, for some of the stockholders may be directors and some of the directors may be executive officers. But so far as legal theory is concerned each group has its own distinct functions and only those of the directors and the executive officers are regarded as functions of management. Of these two groups the board of directors is the central authority in the management of the business and usually included within its major duties will be that of selecting and supervising the executive officers. Thus, the function of choosing the corporate officers ordinarily falls within the scope of the rule that the affairs of a corporation shall be managed by its board of directors. ${ }^{13}$

101 S. W. (2d) 905 (Tex. Civ. App. 1937), (1937) 85 U. of PA. L. Rev. 849. If the term of the employment is limited, a court may uphold the contract, as in Realty Acceptance Corp. v. Montgomery, 51 F. (2d) 636 (C. C. A. 3d, 1930), where the duration of the contract was five years.

13. An examination of the general corporation statutes of the various states reveals that eleven states seem to have no explicit statutory provision as to the manner of electing the corporate officers. But since most of the corporate powers are exercised by the board of directors, in those states it would be reasonable to conclude that the election of the officers is a function properly belonging to the board of directors. The statutes of thirteen states expressiy provide that the president, secretary, treasurer and other officers shall be elected by the board of dirctors. Of the statutes of seven states providing that the president, secretary and treasurer shall be elected by the board of directors, three provide that the other officers shall be elected in the manner set forth in the by-laws, and four in the manner provided in the by-laws or determined by the board of directors. Six provide that the president, secretary and treasurer shall be elected by the board of directors and say nothing as to the manner of election of the other officers. Two provide that all the officers shall be elected in the manner provided in the by-laws and two more that all the officers shall be elected in the manner provided in the by-laws or in the certificate of incorporation. In one state the provision is that the prusinlent, secretary and treasurer shall be elected by the board of directors or as determined by the by-laws. Another has the provision that the president shall he elected by the stockhoiders and the other officers as provided in the by-laws. In five, Delaware, New Jerscy. Men Mexico, 
Outside the corporate management lie the stockholders, who in legal theory are supposed to have no control over the management of the corporate affairs save that which they possess by reason of their power to elect the members of the board of directors once each year. Having elected the directors the power of the stockholders is regarded as being exhausted until the next election, except in reference to certain special matters in which they are consulted by reason of statutory, charter, or by-law provisions. Once elected the directors are supposed to perform their duties with the view of furthering the interests of the corporation as a whole and not the interests of the particular stockholders who elected them, save in so far as the latter happen to coincide with the former. Thus, the law regards the directors as being in no sense the agents of the stockholders, but on the contrary insists that in performing their functions they exercise an independent and uncontrolled judgment. This theory is said to be founded on a public policy, one of the purposes of which is to protect the stockholders of the corporation, and to a lesser extent, its creditors and the general public. Out of it has come the rule that a corporation shall be managed by its board of directors, and any device which tends to lessen the power of the directors in this respect runs serious risk of invalidation by the courts.

The application of this legal theory to the practical situation of a corporation with a single majority stockholder at once reveals certain inconsistencies. There is no doubt but that the majority stockholder is in a position to and often does exercise a substantial amount of control over the board of directors, and through them over the executive officers as well. Frequently the majority stockholder will be both a director and an executive officer and thus participate directly in the management of the corporate affairs. In other instances he will not occupy these positions, but will be content with exercising an indirect but no less effective control by means of his power to dominate the board of directors. Where the majority stockholder is another corporation the situation is much the same, the influential persons usually being the directors and executive officers of the majority stockholder-corporation. In any event the majority stockholder normally possesses the ultimate power to determine who shall be both the directors and the executive officers of the corporation.

Legislatures, courts, and legal writers have all recognized the patent danger in the possibility that the majority stockholder will control the corporation for his own benefit without regard for the interests of the minority stockholders, who, unrepresented on the board of directors,

North Carolina and Pennsylvania, the statutes provide that the president, secretary and treasurer shall be elected either by the board of directors or by the stackholders, as determined by the by-laws. As to the relevance of the statutes of these five states to the problem under consideration here, see page 1098, infro. See also note 33, infro. 
may be unable even to ascertain what goes on in the management of the corporate affairs. Largely with this in mind many states have curtailed partially the power of the majority stockholder by providing for cumulative voting in the election of directors. As another protection the courts have developed the doctrine, now of ten included in corporation statutes, that in certain situations giving rise to a conflict of interest the relation between the majority stockholder and the minority stockholders will be regarded as a fiduciary one. Thus, in many instances the underlying legal theory has been modified to meet the realities of the situation, and a similar modification of the rule that the business of a corporation shall be managed by its board of directors would be quite proper so far as the type of contract here under consideration is concerned.

To consider the problem more specifically, it is helpful first to look at its broad outlines and then to examine particular cases. The contract ordinarily imposes two basic obligations upon the majority stockholder, the one that the contracting minority stockholder shall be a director of the corporation, and the other that he shall hold a specified executive position. The first of these two obligations is very analogous to the so-called "pooling agreements" by which several stockholders, none of whom has a majority stock interest, agree to vote their shares as a unit so that certain individuals, usually themselves, will be elected directors. Though in a few states serious doubts exist, the first provision generally is recognized today as a perfectly legal device. ${ }^{14}$ It will not be discussed further here, and attention will be concentrated on the second obligation where the situation is much more confused.

The second duty imposed upon the majority stockholder by the contract, through which the minority stockholder is attempting to assure himself of his position in the corporate management, has not fared so well in the courts. Today, unless all the stockholders are parties to the agreement, it will be invalidated on the ground that it contravenes the fublic policy embodied in the rule that a corporation shall be managed by its board of directors. ${ }^{15}$ The line of argument usually advanced is

14. To attain its position of respectability this first obligation underwent years of attack in the courts. These attacks were based on another public policy argument, which in some aspects was very similar to the one made against the type of contract under consideration here. Decisions upholding this first obligation include Faulds v. Yates, 57 Ill. 416 (1870) ; Thompson v. Thompson Carnation Co., 279 I1l. 54, 116 N. E. 648 (1917); Brightman v. Bates, 175 Mass. 105, 55 N. E. 809 (1900). See Manson v. Curtis, 223 N. Y. 313, 319, 119 N. E. 559. 561 (1918); McQuade v. Stoneham, 263 N. Y. 323, 329, 189 N. E. 234, 236 (1934); Withers v. Edmonds, 26 Tex. Civ. App. 189, 191, 62 S. W. 795, 796 (1901). Contra: Haldeman v. Haldeman, $176 \mathrm{Ky} .635 .197$ S. WV. 376 (1917) ; Lothrop v. Goudeau, 142 La. 342.76 So. 794 (1917) ; Creed v. Copps, 103 Vt. 164, 152 Atl. 369, 71 A. L. R. 1287 (1930).

15. Decisions upholding such contracts where all the stockholders were parties include Kantzler v. Bensinger, 214 III. 580, 73 స. E. 874 (1905); Hayrden v. Beane, 199 N. E. 755 (Mass., 1936) ; Clark v. Dodge, 269 N. Y. 410, 199 N. E. 641 (1036). Thiese 
that such a provision imposes limitations on the power of the board of directors to manage the corporate affairs by preventing the directors from exercising an independent and uncontrolled judgment in the selection of the executive officers and in fixing their compensations and terms of office. This argument finds expression in either of two ways. In some opinions it is reasoned that because the corporate device is solely a creature of the state, it can be utilized only in accordance with the rules laid down by the state. Since amung tirese rules is the nne that the affairs of a corporation shall be managed by its board of directors, adherence to that rule is a prerequisite to the use of the corporate device and any departure from it will be held invalid. ${ }^{16}$ In other decisions the principal emphasis is upon the idea that limitations imposed upon the judgment of directors are necessarily injurious to other stockholders who are not parties to the contract, ${ }^{17}$ or in rarer instances, to other classes of persons who need protection. ${ }^{18}$ The consideration moving the latter group is in reality the

cases should not be interpreted as indicating that a tendency is developing to regard the fact that all the stockholders are parties to the contract as creating an exception to the rule. The propar approach instead would seem to be that this fact is relevant only in that it conclusively shows that there are no non-contracting minority stoclaholders whom the contract can injure.

16. In Manson v. Curtis, 223 N. Y. 313, 323, 119 N. E. 559, 562 (1918), the court said, "Directors are the exclusive, executive representatives of the corporation and are charged with the administration of its internal affairs and the improvement and use of its assets. Clearly the law does not permit the stockholders to create a sterilized board of directors. Corporations are the creatures of the state and must comply with the exactions and regulations it imposes." See also Rush v. Aunsp3ugh, 179 Al3. 542. 546. 60 So. 802, 803 (1912); Smith v. California Thorn Cordage, 129 Cal. App. 93, 93, 18 P. (2d) 393, 395 (1933); Jackson v. Hooper, 76 N. J. Eq. 592, 603, 75 At1. 563, 573 (1910); Haldeman v. Haldeman, 176 Ky. 635, 645, 197 S. W. 376, 380 (1917). Such a consideration opens up the much debated question of the extent to which the corporation may be used as a device under which to operate an individual or corporate enterprise. Jaclison v. Hooper, supra; Seitz v. Michel, 148 Minn. 80, 181 N. W. 102 (1921); Salomon v. Salomon \& Co., [1897] A. C. 22.

17. Haldeman v. Haldeman. 176 Ky. 635, 197 S. W. 376 (1917) ; Seripps v. Siveency; 160 Mich. 148, 125 N. W. 72 (1910); Seitz v. Michel, 148 Minn. 80, 181 N. W. 102 (1921) ; McQuade v. Stoneham, 263 N. Y. 323, 189 N. E. 234 (1934); Timme v. Kopmeier, 162 Wis. 571,156 N. W. 961 (1916). The usual fear of the courts is that the contracting minority stockholder will get some private benefit from the contract at the expense of the other minority stockholders. Rany courts regard the employment of tite contracting minority stockholder at a definite compensation for a period of years as i "Iucrative position" conferring on him special benefits. Regardless of the fact that the corporation may have to hire someone for the position anyway, and without lumbing to see whether the salary and the term are reasonahle, some courts will say that such a contract results in injury to the non-contracting minority stockholders. Clark v. First Nat. Bank of Ottumwa, 219 Iowa 637, 259 N. W. 211 (1935): Guernsey v. Cook, 120) Mass. 501 (1876); Thielsen v. Blake, Mloffitt \& Towne, 142 Ore. 59, 17 P. (21) 5 (10 (1932); Withers v. Edmonds, 26 Tex. Civ. App. 189, 62 S. W. 795 (1901).

18. Cf. Thomas v. Mathews, 94 Ohio St. 32, 113 N. E. 669 (1916); Seitz v. Michel, 148 Minn. 80, 181 N. W. 102 (1921). In all the cases involving banks, it would scem 
basis of the reasoning relied upon by the former, for the purpose of the state in laying down this particular rule is chiefly to protect these various classes of persons. But from the stress placed on the first rationale it seems that the policy of requiring adherence to this fundamental canon of corporation law is sufficiently important to some courts to be regarded as an end in itself.

The dual status of the majority stockholder who is also a.director results in the possibility that limitations may be imposed upon the board of directors directly and indirectly. Since in a great many cases the majority stockholder is in fact a director, the contract operates upon him directly in that capacity, and upon this fact the reasoning of many courts is founded. As a director the relation of the majority stockholder to all the stockholders is that of a fiduciary and his duty at all times is to act for their best interests by exercising his independent and uncontrolled judgment in all corporate matters, whether it be the selection of the executive officers or some other question of management. By obligating himself to keep the contracting minority stockholder in a certain exrecttive position, the majority stockholder can exercise that independent and uncontrolled judgment only at the risk of incurring legal liability. In that one respect he no longer is managing the corporate affairs and has become merely a passive director. Therefore, so the argument runs, the contract violates public policy and is illegal. ${ }^{10}$

Regardless of whether the majority stockholder is a director, the contract may impose these same limitations indirectly. While the argument of the courts on this point rarely is made clear, in substance it would seem to be that the contract obligates the majority stockholder to elect a board of directors which will be subservient to his will so far as the selection of the contracting minority stockholder for a specified executive position is concerned. Indulging in the realistic assumption that the directors will respect the wishes of the majority stockholder, the courts find that they are prevented from exercising an independent and uncontrolled judgment and thereby become passive. They are no longer man-

possible to argue that depositors, as a special class of creditors, are especially in need of protection.

19. West v. Camden, 135 U. S. 507 (1890); Teich v. Kaufman, 174 Ill. App. 306 (1912) ; Noel v. Drake, 28 Kan. 265 (1882); Guernsey v. Cook, 120 Mass. 501 (1876); Dickson v. Baker, 75 Minn. 168, 77 N. W. 820 (1899); Van Slyke v. Andrews, 146 Minn. 316, 178 N. W. 959 (1920); Jacobson v. Barnes, 176 Minn. 4, 222 N. W. 341 (1928); Dubbs v. Kramer, 302 Pa. 455, 153 Atl. 733 (1933). Cf. Gage v. Fisher, 5 N. D. 297,65 N.W. 809 (1895); Hampton v. Buchanan, 51 Wash. 155, 98 Pac. 374 (1908); Timme v. Kopmeier, 162 Wis. 571,156 N. W. 961 (1916). In Dubbs v. Kramer, supra, the court even went so far as to approve the language of the lower court, which had said that a director "cannot contract to use his vote for the benefit of anyone else, or even for the benefit of the corporation." 
aging the corporate affairs and the contract consequently is illegal.: ${ }^{20}$ The theoretical possibility that the board of directors might disregard the wishes of the majority stockholder is regarded, as so remote that usually it is not deemed to merit even passing mention. ${ }^{21}$

From this brief summary of the lines of reasoning upon which contracts of this type are invalidated, it will be noticed that one idea stands out-the directors are prevented from exercising a free and independent judgment in the selection of an executive officer and in that one respect they have become a passive body. This predominance appears more clearly when specific cases are considered. In the often-cited Manson $v$. Curtis, ${ }^{22}$ the agreement went much farther than the ordinary contract outlined above and demonstrates quite distinctly what the courts mean when they speak of a passive directorate. In substance the contract provided: (1) that the majority stockholder and the minority stockholder should each have the right to name three directors and that a seventh director should be named by a disinterested party to be mutually agreed upon by the two of them; (2) that for one year the minority stockholder should manage the corporate business, having the exclusive right not only to administer the corporate affairs, but also to formulate the corporate policies; and (3) that the president of the corporation "should be only a nominal head as president." The court interpreted the contract in the light of these and other provisions as creating not only a passive president, as it did specifically, but also by necessary implication a directorate which was wholly subservient to the minority stockholder and which in the language of the court was "a sterilized board of directors." The court held that this contract was clearly contrary to public policy and that it could not support an action for damages against the majority stockholder for failure to carry out his obligations. The differences between this contract and the ordinary agreement here under consideration seem very evident, for it not only provided for the participation of the minority stockholder in the corporate management, but also went on

20. This is largely spectlation as to the line of argument a court actually would take to invalidate such a contract. Clear cut decisions in this type of situation are extremely scarce, for the majority stockholder is almost invariably a directer, and where the majority stockholder itself is a corporation, the manner in which the bourd of direc. tors is rendered passive is not made clear. Thielsen v. Blake, Moffitt \& Toune, 142 Ore. 59, 17 P. (2d) 560 (1932). On the other hand cases can te found saying that since stockholders are not fiduciaries, they may contract among themselves practically as they please. See Bausch \& Lomb Optical Co. v. Wahlgren, 1 F. Supp. 799, 803 (N. D. Ill. 1932), aff'd on other grounds, 68 F. (2d) 660 (C. C. A. 7th, 1934), cert. denied, 292 U. S. 639 (1934). Cf. Realty Acceptance Corp. v. Montgomery, 51 F. (2d) 635 (C. C. A. 3d, 1930).

21. But see Clark v. Dodge, 269 N. Y. 410, 416, 199 N.E. 641, 643 (1936); Fantzler v. Bensinger, 214 IIl. 589, 598, 73 N.E. 874, 877 (1905).

22. 223 N. Y. 313,119 N. E. 559 (1918). 
to attempt to vest in him the sole power to control the business of the corporation, without consulting the board of directors, the other officers, or even the majority stockholder.

These differences become more apparent by comparing the contract in Manson v. Curtis with more typical contracts in three fairly recent cases. In McQuade $v$. Stoneham ${ }^{23}$ the majority stockholder in the corporation which operates the New York Giants' baseball team entered into a contract with two minority stockholders, one of whom was the immortal John McGraw and the other McQuade, the plaintiff in the case. By this contract the three of them agreed "to use their best endeavors for the purpose of continuing as directors of said Company and as officers thereof", the majority stockholder as president at an annual salary of $\$ 45,000, \mathrm{McGraw}$ as vice-president at $\$ 7,500$, and McQuade as treasurer at $\$ 7,500$. The contract further provided that "there shall be no change in the said salaries . . . or any matters regarding the policy of the business of the corporation or any matters which in anywise affect, endanger or interfere with the rights of the minority stockholders, excepting upon the mutual and unanimous consent of all the parties hereto." In addition, the contract was to continue in force so long as the three parties to the contract, or any of them, owned the shares of stock which they owned at the date of the agreement. After a period of years during which the corporation apparently was operated successfully under this arrangement, the majority stockholder and McQuade disagreed upon purely personal matters. ${ }^{24}$ As a consequence the majority stockholder prevented the re-election of McQuade to his positions as director and treasurer of the corporation. A suit by McQuade against the majority stockholder for damages for wrongful discharge was dismissed by the Court of Appeals of New York (with two judges dissenting on the point here under consideration) on the ground that the contract was against public policy and therefore unenforcible. ${ }^{25}$ The majority adhered

23. 263 N. Y. 323,189 N. E. 234 (1934), (1935) 44 Y YLE L. J. 873. The majority stockholder in the case was the late Charles Stoneham, well known to the sports pages as the owner of the Giants. In addition to serving as vice-president, the late John McGraw managed the baseball team, and in that capacity was probably the most renowned of all big league managers. The ten National League pennants which the team won under his guidance would seem indicative of his value to the corporation. While MicQunde's services do not appear to have been of such a spectacular nature, possibly they had their own peculiar value at the time the contract was made. See note 25 , infra.

24. The trial court expressly found that the reason for McQuade's discharge was a series of personal quarrels with Stoneham which had no effect on the orderly and efficient management of the corporate business, and also that McQuade "was removed by Stoneham for protecting the corporation and its minority stockholders."

25. A second ground upon which the decision was based was that at the time the contract was made and until after his discharge, MeQuade was a New York City magistrate. By statute city magistrates were prohibited from "engaging in a business." The entire court regarded McQuade's duties as treasurer of the corporation as falling with 
to the usual line of argument, as is illustrated in the following excerpts from the opinion:

"The stockholders may not, by private agreement among themselves, control the directors in the exercise of the judgment vested in them by virtue of their office to elect officers and fix salaries. . . .

"Stockholders may, of course, combine to elect directors. That rule is well settled. . . . The power to unite is, however, limited to the election of directors and is not extended to contracts whereby limitations are placed on the power of directors to manage the business of the corporation by the selection of agents at defined salaries."

The majority opinion recognized the fact that contracts such as the one before the court often did exist, tacit or otherwise, for convenience in administering the affairs of corporations. It mentioned the fact that there were other minority stockholders in the corporation who were not parties to the contract. But instead of emphasizing the most vulnerable feature of the contract, namely the provision that there should be no change in the business policy of the corporation without the unanimous consent of the contracting parties, the majority stressed the point that the task of passing on the question of whether public policy had been violated sufficiently to require the invalidation of any particular contract was one which courts were not properly qualified to perform. Therefore, rather than attempting to ascertain whether the non-contracting stockholders were in any wise endangered by the contract before the court, it laid down an arbitrary rule for all situations by which all such contracts are rendered unenforcible. ${ }^{28}$

The point of view of the majority was severely criticized in the dissenting opinion. Treating the problem on a practical level, the dissenting judges pointed out that the majority stockholder by reason of his stock ownership actually did control the board of directors, and consequently was in a position to prevent the directors from ever exercising a really independent and uncontrolled judgment in the selection of the corporate officers. By the contract in question the majority stockholder had agreed merely to share this control with McQuade and the other contracting minority stockholder, and in this sharing of control the dissenters could see nothing illegal. It was admitted that if the contract represented a

the prohibition of this statute, and that as a consequence he could not recover damages "for loss of opportunity to perform services forbidden by law"

26. The majority said, "We are constrained by authority to hold that a contract is illegal and roid so far as it precludes the board of directors, at the risk of incurring legal liability, from changing officers, salaries, or policies or retaining individuals in office, except by consent of the contracting parties. On the whole such a holding is preferable to one which would open the courts to pass on the motives of directors in the lawful exercise of their trust." See also Jacobson v. Barnes, 176 Minn. 4, 7, 222 N. W. 341, 342 (1928); Teich v. Kaufman, 174 Ill. App. 305, 312 (1912). 
"corrupt bargain" by which the three contracting stockholders were seeking to despoil the corporation, as for example by taking excessive salaries, the contract would be unenforcible, but that in the absence of such a factor "public policy should be governed by facts and not by abstractions." Otherwise, the principal result of the majority holding was declared to be the encouragement of sharp practice on the part of majority stockholders in such situations.

The sequel to McQuade v. Stoneham was Clark v. Dodge, ${ }^{27}$ which was decided in 1936, two years later. The provisions of the contract involved have been outlined above, being in substance that the minority stockholder should be a director and the general manager of the corporation, and that in the latter capacity he should receive one-fourth of the net income of the corporation either by way of dividends or by way of salary. After conducting the business for about thirteen years under the contract, the minority stockholder was ousted by the majority stockholder from both of his positions, whereupon be brought an action for specific performance to compel his reinstatement. The Appellate Division dismissed the complaint on the authority of $M c Q u a d e v$. Storeham. On appeal this holding was reversed and the complaint held to state a cause of action. ${ }^{23}$ In an opinion written by one of the dissenters in McQuade $v$. Stonehasm, the Court of Appeals clearly departed from the majority view in that decision and indicated that while as a general rule the function of the selection of the corporate officers was to be performed by the board of directors, that rule was merely a "norm" from which variations would be permitted so long as no one was injured by the enforcement of the contract. Regarding the limitations imposed by the contract on the power of the directors as very slight, the court looked to see whether the contract actually injured or threatened to injure anyone. Since the directors were the sole stockholders and were all parties to the contract, the court could conceive of no one whom the enforcement of the contract could possibly injure. Accordingly it could see no reason why the majority stockholder should not be held to his bargain. ${ }^{20}$

27. 269 N. Y. 410, 199 N. E. 641 (1936), (1936) 36 Cor. L. Rev. 836.

28. The wisdom of entertaining a suit for specific performance of such a contract is questionable upon practical grounds. To decree specific performance would compal the contracting minority stockholder and the majority stocl-holder to be associated together in the management of the corporation. Such a forced relationship would rarely be harmonious and might definitely injure rather than benefit the corporation. Consaquently, in most cases it would seem that an action for damages would be a viser remady.

29. Three of the five judges who constituted the majority in McQuade v. Stonehom were still on the court in 1936. No doubt the peculiar circumstances of Clarle v. Dodge were more responsible for their change of mind than any sudden alteration in their logic. The case strikingly portrayed the hardships which could ensue from the strict application of the rule of $M c Q$ uade $v$. Stoneham, for the plaintiff, a chemist, had turned over to the corporation secret formulae known only to him in exchange for the rights given him under the contract, and presumably these formulae were among the more valuable assets 
The last of the three recent cases is Hayden $v$. Beane, ${ }^{80}$ where two stockholders. who owned all the voting stock of the curpuration, wished to secure the services of an individual named Hayden as the general manager of the corporation's distillery. ${ }^{31}$ In order to induce Hayden to take this position the two stockholders agreed: (1) that they would transfer to Hayden twenty-four shares of stock in the corporation, thus making him a minority stockholder; (2) that they would cause to be elected to the board of directors Hayden and such other person as Hayden should nominate; (3) that they would elect as the three remaining directors such individuals as would continue Hayden in the office of president of the corporation so long as he should "faithfully and honestly serve it"; and (4) that they would not sell their stock except to each other without first offering it to the board of directors, who might purchase it for the corporation or for themselves individually. In turn Hayden agreed to accept election to the positions of director and president pro-

of the corporation. To invalidate the contract would have baen so patently unjust that the rule, accordingly, was modified.

30. 199 N. E. 755 (Mass. 1936). In a more recent case, Mansfield v. Lang, 200 N. E. 110 (Mass. 1936), the plaintiff was majority stockholder in each of two corporations and the defendant opred the controlling interest in a third corporation, all three of which were engaged in the problishing business. Having decided to combine the three enterprises, the plaintiff and defendant entered into a contract to organize a holding company, and by which the plaintiff was to "undertake the actual management of the combined companies" for at least three years at a monthly salary of $\$ 500$. Upon completion of the organization of the holding company the defendant held a majority of its shares, the remainder being owned by the plaintiff and two other persons, one of vhom was a relative and the other a close friend of the majority stockholder. After the business had been operated about a year under this arrangement, the board of directors of the holding company discharged the plaintiff from his position of general manager. The plaintiff sued the defendant for breach of the agreement and was allowed to recover damages.

The case is unusual so far as the question of injury to the non-contracting stochholders is concerned. In the holding company the two non-contracting stockholders were closely associated with the majority stockholder and had complete knowledge of the transaction, one of them even witnessing the signing of the agreement. Hence, the element of secrecy in the making of the contract was absent and the non-contracting stockholders can be said to have acquiesced in the action of the majority stockholder. But the contract called not only for the plaintiff to manage the holding company, but also the three subsidiaries. The two subsidiaries in which the plaintiff had held the controlling interest had minority stockholders who were not parties to the contract and possibly had no knowledge of its precise terms. On the other hand the plaintiff was their representative in the management of the combined businesses and the consequence of his ouster might well be to harm rather than benefit their interests.

31. The statement that the entire stock of the corporation was owned by the two individual defendants appears in the court's opinion. Actually, however, the agreement also was signed by a third person who either was a stockholder at the date of the contract or became one prior to its breach. No information could le obtained as to the exact proportion in which these three held the stock, but apparently they worked together as a unit so that for the purposes of the problem here they may be regarded as occupying the position of a single majority stockholder. 
vided he was tendered also a contract acceptable to him arranging for his services as general manager of the corporation for seven years. After Hayden had been elected a director and president differences developed and the majority stockholders refused to transfer to him the twenty-four shares of stock. Still later they caused another person to be elected director and president in Hayden's stead. Hayden then sought by a bill in equity to have the shares owned by the majority stockholders applicd in satisfaction of his claim for damages. In this proceeding the majority stockholders entered a demurrer raising the defense that the contract contravened public policy. In overruling the demurrer and holding the contract valid, the court pointed out that all the stockholders were parties to the contract. The point of view taken by the court is illustrated in the following quotation from the opinion:

"It is evident from these provisions of the contract that the individual defendants believed that the best interests of the corporation required that the plaintiff be elected to those offices and that he should serve as its general manager for a term of at least seven years. The agreement so far as appears was entered into by the parties in good faith with the mutual understanding and belief that it would result in benefit to the corporation and to the stockholders. We are unable to find that it was against public policy or illegal on any other ground."

The fact that in Clark v. Dodge and Hayden v. Beane the courts upheld contracts of the type under consideration here is significant. But of even more importance is the method adopted by those courts to ascertain whether or not such contracts should be invalidated on the ground of public policy. In looking at the specific contracts involved in the cases before them to see whether they actually injured or threatened to injure anyone, and in applying the rule that the affairs of a corporation shall be managed by its board of directors as a relative instead of an absolute standard, these courts have commenced what seems to be a departure from the traditional point of view. This departure is to be welcomed for the tendency of most courts to invalidate similar agreements produced many results which were clearly inequitable and unnecessary, and indeed, rather than furthering any public good, militated against it. The traditional approach has been quite unrealistic and the line of argument used to support the results reached has often been unconvincing. It is high time for many other courts to reappraise this rule of public policy and permit recovery of damages, as did the New York and Massachusetts courts in Clark 2 . Dodge and Hayden v. Beane. ${ }^{82}$

32. It should be pointed out that a contract of this type can never afford the contracting minority stockholder a right of action against the majority stockholder where he has been discharged from his executive position for cause. A condition of every con- 
In making such a reappraisal it should be pointed out that the present quarrel is not with the rule of public policy itself so much as it is with the manner of its application to the one particular situation of a corporation with a single majority stockholder. ${ }^{33}$ One feasible method of applying the canon in a manner which will achieve the most desirable results possible is to analyze the facts of each particular case by making two inquiries. The first inquiry is whether the contract involved in the case has caused or threatens to cause some actual and tangible injury to the non-contracting minority stockholders, who are most likely to be endangered, or to anyone else. Since in the ordinary case the answer will be in the negative, a second inquiry must then be made as to the extent to which the contract limits the ability of the board of directors to reach an independent and uncontrolled judgment in matters or corporate management, or stated differently, the extent to which the contracts causes a deviation from the rule that the affairs of a corporation shall be managed by its board of directors.

To elaborate on these two inquiries, it should be clear that the first is purely a practical one. It should be made wholly without regard to the existence of the rule that the board of directors shall manage the business of a corporation, for the question is simply whether it can be demonstrated that some pecuniary damage has resulted or will result to the non-contracting minority stockholders if the contract is upheld. For

tract is that he will be competent, honest and loyal. Often this condition will be express as in the contracts in Clark v. Dodge and Hayden 2. Beame, and where not so expressed, it will be implied by the court. Fells v. Katz, 256 N. Y. 67, 175 N. E. 516 (1931). But cf. Matter of Allied Fruit \& Extract Co., 243 App. Div. 52, 276 N. Y. Supp. 153 (1st Dep't 1934).

33. In view of the tendency of most courts to regard the rule as a prophylactic measure designed to prevent any interference with the board of directors, it seems that the most useful approach is to assume that the rule is justified as a general principle of corporation law and then seek to apply it in a manner which will achieve the most beneficial results possible. However, it can be argued with considerable force that the sole purpose of the rule is to protect minority stockholders, and, consequently, a showing in a given case that no injury can result to them from the contract would malse an application of the rule so totally unjustified that even an agreement which divested the directors of all their functions should be upheld. This argument carries particular weight in respact to selecting corporate officers, for this function is not one which peculiarly belongs to the board of directors, as is demonstrated.by the fairly recent enactment in several states of statutes expressly permitting the stockholders to choose the officers. DEr. REr. CODE (1935) §2042; N. J. Rev. Stat. (1937) tit. 14, c. 7, §6; N. M. Stat. A:is. (Courtright, 1929) §32-113; N. C. Code Ann. (Michic, 1935) §1144; PA. Stat. Anso. (Purdon, Supp. 1938) tit. 15, §2852-406. Moreover, inplicit permission to the same effect exists in five other states where statutes provide that officers shall be selected: (1) either by the directors or as provided in the by-laws (Mfaryland); (2) as prescribed in the certificate of incorporation or in the by-laws (Mfinnesota and Rhode Island); and (3) as provided in the by-laws (Florida and Wyoming). Under such provisions it would seem that the function of selecting the officers could properly be alloested to the stodiholders. 
example, such damage may occur where the contracting minority stockholder manifestly is incompetent to perform the duties of the specified executive position, or where the rate of compensation provided for in the contract is grossly unreasonable. ${ }^{\text {s }}$ Though variations in degree may be present, a court often will be able to perceive readily the precise injury which has occurred or which is certain to occur and trace it in part at least to the existence of a contract of this type. In such a case there is no quarrel with the application of this rule of public policy for it affords a convenient method of remedying a wrong done.

But in the vast majority of the decided cases no such tangible injury or threat of injury to the non-contracting minority stockholders, or to anyone else, is present. Instead the situation will be one where after the contract has been in force, some difference, often purely personal as in McQuade $v$. Stoneham, develops between the parties to the contract. Then the majority stockholder ousts the contracting minority stockholder from his executive position, and when sued for breach of contract the majority stockholder falls back on the rule of public policy as a justification for his action. Logically, if it can be demonstrated that no minority stockholder can possible be harmed by the contract, the reason for the rule would seem to disappear and the contract should be upheld. But since it always is extremely difficult to point out any specific damage to the non-contracting stockholders, who are not even parties to the suit, ${ }^{\mathrm{s5}}$ many courts will pass over this possibility of injury and rely upon the fact that in limiting the power of the board of directors to form an independent and uncontrolled judgment the contract violates a hallowed precept of corporation law. So it is to this aspect of the problem that the second inquiry is directed.

Accepting the attitude that observation of the rule that a corporation shall be managed by its board of directors is an end in itself, a possible solution is to regard that rule as setting a standard. But since it is believed for various reasons set forth above that it is highly undesirable to make this standard an absolute one, as did the court in McQuade v. Stoneham, the better point of view is to treat it as an approximation

34. The courts frequently must pass on questions involving the reasonableness of a salary or of a term of employment, and while such questions may be difficult to decide, they are not impossible. E.g., Sagalyn v. Meekins, Packard \& Wheat, Inc., 290 Mass. 434, 195 N: E. 769 (1935) ; Seitz v. Union Brass \& Metal Mfg. Co., 152 Minn. 460, 189 N. W. 586 (1922).

35. In wily one case has a non-contracting minority stockholder intervened and attacked the validity of the contract. In Haldeman v. Haldeman, $176 \mathrm{Ky} .635,197 \mathrm{~S}$. W. 376 (1917), the corporation involved published the Louisville Couricr-Journal. Colonel Henry Watterson, its famous editor and Democratic leader, was the non-coutracting minority stockholder. He intervened in the suit and claimed his minority interest was prejudiced by the contract. In invalidating the contract the court quite properly placed considerable emphasis on his intervention. 
from which reasonable deviations will be permitted. Thus, the problem becomes one of fixing the limits within which these deviations will be allowed in the belief that such reasonable deviations will not injure anyone. One illustration is furnished by Clark v. Dodge where, the question of actual injury to anyone being absent, the court held that the departure from the standard set by the rule of public policy was so slight as to make application of the rule unnecessary. Another is Manson v. Curtis where, despite the allegation that the breach of the contract by the majority stockholder had rendered the corporation's stock worthless, the deviation from the standard was so great the court felt that the contract should not be enforced. There the emphasis was not on the injury or threat of injury to non-contracting stockholders, but on the departure from a principle, adherence to which the court said was "absolutely necessary."

Considered in this manner the problem becomes one of whether the ordinary contract of this type amounts only to a slight deviation which should be permitted or to a great one which should be forbidden. At most the board of directors is prevented by such a contract from reaching an independent and uncontrolled judgment in only three respects. The directors have no choice but to select the contracting minority stocltholder for the executive position specified in the contract, they have no discretion in fixing the amount of compensation which he shall receive, and finally they have no control over the length of time for which he shall hold that office. Even though its purpose is to secure a skilled executive to superintend the entire business of the corporation, the usual contract never purports to give him any dictatorial power over the board of directors. His decisions in managing the business are still subject to the control of the directors, and certainly the most important function of the board, that of formulating corporate policies, is but little limited by the agreement. In some instances it is true that more than one minority stockholder will be assured a position in the management by the contract so that all the executive offices may be filled in accordance with its terms, but even so the question remains one of degree and the directors still will have a substantial amount of control. ${ }^{30}$ But confining the problem to the usual

36. Where it is evident that such a contract is part of a scheme by which one or more individuals are "purchasing" positions in the corporate management, ample justification for invalidating the contract exists. However, this is more likely to occur in the situation where a number of stockholders, none of whom own a majority stock interest, band together for the purpose of getting one or more of their number a particular office or offices. Cf. Morel v. Hoge, $130 \mathrm{Ga} .625,61 \mathrm{~S}$. E. 487 (1903); Williams v. Fredericks, 187 Ia. 987, 175 So. 642 (1937); Cone v. Russell, 48 N. J. Eq. 203, 21 Atl. 847 (1891). The distinction between these two situations has been recognized by one court. See In re Will of Pittock, 102 Ore. 159, 176, 199 Pac. 633, 638, 17 A. L R. 218 (1921), where the court said, "The vicious principle of illegal combination of directors to pursue certain policies generally for their own aggrandizement seems to be that each surrenders 
situation it seems that such a contract falls far short of creating a passive directorate and that the deviation from the standard set by the rule is so slight as not to justify invalidation of the contract.

That this is the proper conclusion is demonstrated more forcibly when attention is focused on the peculiar position of the single majority stockholder. As pointed out heretofore, the idea that such a contract renders the directors passive is based upon the recognition of the fact that the majority stockholder actually does control the board of directors. Because of this control it seems evident that even in the absence of a contract of this sort, the board of directors may be subservient to the majority stockholder and always may defer to his judgment in managing the corporate affairs. This is especially true in the small corporation with only a few stockholders, where many of the directors may be little more than dummies. The majority stockholder really manages the corporate business, and an innocent, independent board of directors, ready to be corrupted by the employment contract, simply does not exist.

Inevitably, the majority stockholder has control over the board of directors. All he does by this type of contract is to share that control with a minority stockholder. It would be difficult for the contract to render passive a board of directors which is already passive. Though it may be argued that where such a contract exists the majority stockholder is more likely to use his control than where there is no contract, the question is but one of degree and the principle remains the same. Viewed thus, it is immaterial that the majority stockholder, in either his capacity as director or as majority stockholder, may be regarded as occupying a fiduciary position. This fiduciary argument may have some merit where the majority stockholder derives some personal advantage from the contract, as for example, where he receives a pecuniary consideration from the contracting minority stockholder for entering into the agreement. But in most cases no such element of private gain is present. ${ }^{37}$ Indeed, with at least as much force as the public policy argument made by the courts, it may be contended in the same vein that by making such a contract the majority stockholder, rather than limiting

in advance his individual judgment irrespective of the good of the corporation or the rights of the other stockholders. The essence of the fault lies in the combination, which cannot exist where a single majority stockholder, for himself and in the management of his own property, formulates a certain corporate policy and undertakes to carry it out."

37. So far as the argument which is used to invalidate contracts of this type is concerned, the element of private gain to the majority stockholder is not material, and the courts often expressly say so. See West v. Camden, 135 U. S. 507, 521 (1890); Snow v. Church, 13 App. Div. 108, 110, 42 N. Y. Supp. 1072, 107 (2d Dep't 1897). But where it is found in a casc, the court usually will refer to it. Dickson v. Baker, 75 Minn. 168, 77 N. W. 820 (1899); Thomas v. Mathews, 94 Ohio St. 32, 113 N. E. 669 (1916). Cf. McClure v. Law, 161 N. Y. 78, 55 N. E. 383 (1899) ; Thielsen v. Blake, Moffitt \& Towne, 142 Ore. 59,17 P. (2d) 560 (1932). 
his own free and independent judgment, is exercising it in the best interests of the corporation. Where the corporation needs someone to fill a certain executive position, such as that of general manager, it is the contract of the majority stockholder which makes it possible to get the services of the person best fitted for the position.

Obviously a court taking a realistic point of view is able to uphold an agreement of this type more readily than one which places its emphasis on the legal theory. Yet one variety of the ordinary contract has sometimes been upheld on theoretical grounds, which upon analysis strikingly reveal the artificiality of the whole doctrine. This variation occurs where the corporation itself becomes an obligor on the contract along with the majority stockholder in an attempt to give the new executive double assurance of his right to participate in the corporate management. $^{.88}$

The argument made to uphold such an agreement is that ordinarily there is little doubt but that a corporation may enter into a contract hiring some individual, whether a minority stockholder or not, for some position in the corporate management, for a reasonable term at a reasonable compensation. The choice of the individual with whom the contract is made is a function of the board of directors, so that when the directors cause the corporation to enter into a contract with the minority stockholder they actually are exercising their own judgment, and instead of being a passive board they are an active one. The fact that the majority stockholder enters into an obligation similar to that of the corporation is immaterial, for if the legal theory is adhered to, the majority stockholder has no control over the board of directors. ${ }^{30}$ This provides a neat solution for the problem wholly within the rule of public policy that the board of directors shall manage the corporate affairs, since the board is doing exactly that. The weakness of the argument is obvious-the directors, in making the contract on behalf of the corporation, merely are following the wishes of the majority stockholder and hardly are

38. Reed \& Fibre Products Corp. v. Rosenthal, 153 MId. 501, 138 Atl. 665 (1927). Cf. Bausch \& Lomb Optical Co. v. Wahlgren, 1 F. Supp. 799 (N. D. Ill., 1932), aff'd on other grounds, 68 F. (2d) 660 (C. C. A. 7th, 1934), cerl. dented, 292 U. S. 639 (1934). See Haldeman v. Haldeman, 176 Ky. 635, 645, 197 S. W. 376, 380 (1917). Of course, the corporation cannot agree that the minority stoclholder shall be a director, so the sole effect of its being made a party to the contract is in connection vith the obligation that he shall hold a certain executive position.

39. In Reed \& Fibre Products Corp. v. Rosenthal, 153 Md. 501, 138 Atl. 665 (1927), the court said, "If a corporation by contract agrees to do something which it has the power to do, it is to be presumed that it acted for its best interest, and the fact that its largest stockholder jointly and severally entered into the same contract with the other party to it cannot detract from the legality or the enforceabiliy of such a contract. There can be no question of public policy involved, for the reason that the stoclinolder has only bound himself to do what the corporation has theretofore agreed to do." 
exercising an independent and uncontrolled judgment. But a court which said that in this situation the board of directors was just as passive as where the corporation was not a party to the contract could not refuse to go a step farther and say that the board of directors was passive regardless of the existence of any contract. Then it would have to uphold the contract on this latter ground, or else involve itself in a morass of contradictions.

In conclusion it should be emphasized that in the situation of the corporation with a single majority stockholder there seems to be no justification for an arbitrary rule invalidating all contracts of the type under consideration. Within the confines of that situation, the cases involving tangible injury to anyone should be handled on the basis of their own particular facts. As stated by the court in Clark v. Dodge, "damage suffered or threatened is a logical and practical test" and is the one which should be adopted generally. ${ }^{40}$ But whatever the rule of law may be, the reasonable use of such contracts achieves a very practical end. As such, no doubt lawyers will continue to draw them, and if the tendency of the New York court in Clark v. Dodge and that of the Massachusetts court in Hayden v. Beane and Mansfield v. Lang ${ }^{12}$ continues to grow, it would seem that eventually such contracts will be legally acceptable everywhere. In the meantime, a lawyer framing such an agreement for a contracting minority stockholder should resort to every possible device which will lessen vulnerability on the ground that the agreement is against public policy. In a few states there is the possibility of taking advantage of the statutory provisions which permit the stockholders to select the corporate officers. By the enactment of an appropriate by-law provision this function may be allocated to the stockholders and thereupon the rule that a corporation shall be managed by its board of directors would become wholly irrelevant.

But since this method will not be available in most jurisdictions, a lawyer should endeavor to make all the stockholders parties to the contract, as often may be possible in the case of a corporation with only a few stockholders. If this cannot be done he should at least bring the existence of the contract to the attention of the non-contracting minority stockholders, or even better, have them confirm it at a meeting of the stockholders. Much of the dislike of the courts for these contracts lies in their apprehension that the majority stockholder and the contracting

40. In addition to Clark $\%$. Dodge and Hayden $v$. Beane, the following cases tend to support this approach: Weber v. Della Mt. Mining Co., 14 Idaho 404, 94 Pac. 441 (1918); Faulds v. Yates, 57 IIl. 416 (1870) ; Thompson v. Thompson Carnation Co., 279 III. 54, 116 N. E: 648 (1917); Horn v. Nessen Lumber Co., 236 Ill. App. 187 (1925) ; Mansfield v. Lang, 200 N. E. 110 (Mass. 1936) ; Jones v. Williams, 139 Mo. 1, 39 S. W. 486 (1897); Winsor v. Commonwealth Coal Co., 63 Wash. 62, 114 Pac. 908 (1911). See also Comment (1936) 13 N. Y. U. L. Q. REv. 585.

41. See note 30 , supra. 
minority stockholder may defraud the rest of the stockholders by a secret agreement. By informing the stockholders of the existence of the corrtract the attomey will have done much to reduce the chance $c$ s a later holding that anyone was injured by the contract. Then secondly, is the law of his particular jurisdiction permits it, he should have the corporation itself, acting through its board of directors, become a party to the contract along with the majority stockholder. In this way he vill be able to show that the board of directors took some action with respect to the selection of the contracting minority stockholder for the executive position. Thirdly, it may be of some advantage not to have the majority stockholder as a member of the board of directors, and thus eliminate the objection that a limitation has been imposed directly on the exercise by the majority stockholder of his free and independent judgment in his fiduciary capacity as a director. If this is not feasible, at least language should be avoided which expressly binds the majority stockholcer in that capacity. Finally, a lawyer should exercise great care as to the degree to which the contract limits the power of the board of directors to manage the corporate affairs. He should be wary of any provision which purports to confer on the contracting minority stockholder any exclusive power to manage the corporate enterprise and he should attempt to confine the contract to the selection of the minority stockholder for the specified executive office. He should endeavor to be certain that the qualifications of the contracting minority stockholder are suitable for that position and that the compensation is reasonable. If possible, he should limit the term of the contract to the definite number of years which is most likely to be regarded as reasonable in his particular jurisdiction. A lawyer who has done all these things should feel fairly safe that if it is ever necessary to test the validity of the contract, a court will be forced to ridiculous lengths to hold the agreement unlawful. 